\title{
Occupational and Environmental Health Concerns on Unsafe Acts and Conditions in Poultry Production Sites in Ido-Osi, Ekiti State, Nigeria
}

\author{
A. O. Oluyege ${ }^{a}$ and K. O. Ojo ${ }^{a^{*}}$ \\ ${ }^{a}$ Microbiology Department, Ekiti State University, Ado-Ekiti, Nigeria.
}

\begin{abstract}
Authors' contributions
This work was carried out in collaboration between both authors. Author AOO designed the study and managed the analyses of the study. Author KOO wrote the protocols, first draft of the manuscript and managed the literature searches. Both authors read and approved the final manuscript.

Article Information

DOI: 10.9734/ARRB/2021/v36i1230468

Editor(s):

(1) Dr. Md. Aminur Rahman, Jashore University of Science and Technology, Bangladesh.

Reviewers:

(1) Barde Israel Joshua, National Veterinary Research Institute Vom-Jos, Nigeria.

(2) Gadafi Iddrisu Balali, Kwame Nkrumah University of Science and Technology, Ghana.

Complete Peer review History, details of the editor(s), Reviewers and additional Reviewers are available here: https://www.sdiarticle5.com/review-history/65521
\end{abstract}

Original Research Article

Received 10 December 2020

Accepted 20 February 2021

Published 20 December 2021

\section{ABSTRACT}

Aim: Many food animal production facilities are sited close to human residence. This research work seeks to establish the occupational and environmental burdens of unsafe acts and conditions in backyard poultry production sites in the area of study in order to validate the compliance level of poultry farmers to common safety regulations.

Place and Duration of Study: Microbiology Department, Ekiti State University, Ado-Ekiti, from February 2017 to December 2019.

Methodology: A well-structured questionnaire was administered to farm managers and residents within the area of study. Data on poultry management attitudes and history of water use were collected. The coordinates of the poultry sites, natural water bodies, source area and their relative distances were determined using the Geographical System Information Software, Mapit GIS. Fecal droppings from poultry birds were randomly sampled with a sterile swab stick and transferred into a factory-packed polythene bag. The suspension of the fecal droppings was streaked on Eosin Methylene Blue agar plates and incubated at $37^{\circ} \mathrm{C}$ for $18-24$ hours. Waste-water, soil from disposal sites, and poultry feed samples were also collected in sterile universal bottles, serially diluted and cultured. E. coli isolates were characterized using relevant biochemical tests. The modified paper 
disc-diffusion method was used to determine the isolates' sensitivity to nine tested antibiotics. The results were interpreted based on the procedures of the clinical and laboratory standard institutes.

Results: Majority of the poultry farms under survey, $83 \%$ adopted the intensive ranging system of farming while few adopted the free range system. Layers were the most reared, $50 \%$. There was no documented health, safety and regulatory protocols used on all the farms leading to variations in poultry management practices. Accumulated poultry droppings were periodically disposed between 3-4 days into open fields, flowing water bodies and pits. Among the three adopted waste disposal options, disposal into open field was rampant, $67 \%$. Also, some of the poultry farmers, $42 \%$ applied the collected poultry droppings as farm yard manure. Family members constitute the major labor force, $92 \%$ on the farm. There were contacts between few of the farmers and their clients during routine farm activities. Majority of the farmers, $83.3 \%$ were not kitted with commonly-used personal protective equipment while coverall was only used by few. The five natural water bodies found within the area of study were majorly used for agricultural, domestic, and, recreational purposes. There was history of diarrhea in respondents, $12 \%$ with exposure to the water bodies. Socio-demographic data show that young, married-males with tertiary education comprise the major farming population. The relative distance of poultry farms to residential site is $\leq 6$ meters while the proximity of poultry farms to natural water sources is between 160 meters to 4,596 meters. Antibiotic sensitivity test shows that multiple antibiotic-resistant bacteria were present in poultry droppings, waste water and soil from poultry waste disposal sites. Bacterial resistance to the fluoroquinolones, sulphonamide, tetracycline, aminoglycoside and penicillin was high.

Conclusion: The findings on unsafe act audit of the poultry production sites assert that safety of public health is dependent on the quality of water and soil found in human environment. Unsafe acts and conditions with the inherent occupational hazards in poultry production sites are attributed to non-functional health, safety and environment management system. Antibiotic resistant bacteria in poultry droppings constitute biological hazard to humans. Exposure to these biological hazards predisposes the public to infections. Human and environmental health can be improved by reviewing the national guidelines and standards for environmental pollution control.

Keywords: Poultry; safety; unsafe acts and conditions; waste.

\section{ABBREVIATIONS:}

\section{P.P.E : Personal Protective Equipment, MARB : Multiple Antibiotic Resistant Bacteria \\ H.S. E : Health, Safety and Environment, H. S. E. M. S : Health, Safety and Environment Management System, \\ ALARP : As Low As Reasonably Practicable, \\ E. I. A : Environmental Impact Assessment.}

\section{INTRODUCTION}

Most food animal production farms in Nigeria lack waste treatment facilities. Humans residing close to livestock farms and animal waste dump sites may be exposed to antibiotic resistant bacteria normally present in poultry waste [1]. Animal feces are alleged to be potential source of strains of antibiotic resistant bacteria. These bacteria constitute a threat to human health when they contaminate water, and different food sources consumed by man [2]. Antibiotics are used for prophylactic, metaphylactic and therapeutic benefits in poultry [3]. Poultry and other farm animals are the key reservoirs for multiple antibiotic resistant $E$. coli and the use of antibiotics in animal production sites is considered the most important factor that promotes the development, selection and spread of antibiotic resistant microorganisms [4].

Poultry birds can be infected with multiple antibiotic resistant bacteria (M. A. R. B) [2]. During indiscriminate waste disposal, these bacteria can be directly discharged with fecal material from animal sources into water and soil in the environment. M. A.R.B and their genes are pollutants to human environment and are transmissible to humans via interaction with environmental reservoirs such as soil, water, and animals [5]. M. A. R. B have been found in many water sources such as drinking wells, rivers and effluents from waste-water treatment plants. These bacteria can cause and spread bacterial diseases such as typhoid fever through contaminated water $[6,7]$. Besides, they may reach humans indirectly along the food chain through consumption of contaminated food, direct contact with infected animals or biological substances released to the environment. Besides, consumption of food contaminated with 
these bacteria may directly lead to infection such as diarrhea caused by Salmonella typhi, Campylobacter spp. and pathogenic strains of $E$. coli (EHEC) [8]. The resistant bacteria can potentially cause infections and spread to man $[9,10]$. Poultry farmers and their families are occupationally exposed and at risk of contracting infection due to M. A. R. B from their animals [11, 12 and 13].

\section{MATERIALS AND METHODS}

\subsection{Research Tools}

A questionnaire was administered as a data collection tool. Data on safety regulatory measures, poultry management practices and use of natural water bodies were collected from poultry managers and residents in the area of study.

\subsection{Provenance}

The coordinates of the source area (poultry sites), natural water bodies, human residence and their relative distances were determined using the geographical system information software Mapit GIS as described by [14].

\subsection{Study Population and Site}

The study population comprises 12 poultry farms, their managers and 50 residents living close to the five identified natural water sources. Poultry birds such as broilers, turkeys and free range birds were reared in the selected poultry farms in Ido/Osi, Ekiti State.

\subsection{Collection and Culturing of Samples}

Fresh fecal droppings from poultry birds were randomly sampled with a sterile swab stick and transferred into freshly procured, factory-packed polythene bags. Farm feed, water and soil from disposal sites were also collected in sterile universal containers. The samples were immediately transferred to the Microbiology Laboratory, Ekiti State University, Ado-Ekiti. They were cultured within 2 hours of collection [15,1].

\subsection{Antibiotic Sensitivity Test}

Antibiotic sensitivity testing was carried out on the $E$. coli isolates using the modified agar discdiffusion method following the procedures of clinical and laboratory standard institutes, 2013.
Antibiotic discs (Oxoid) comprising ciprofloxacin $(5 \mu \mathrm{g})$, tetracycline $(30 \mu \mathrm{g})$, ofloxacin $(5 \mu \mathrm{g})$, trimethoprim/sulfamethozazole $(1.25 / 23.75 \mu \mathrm{g})$, gentamycin $(10 \mu \mathrm{g})$, amoxicillin-clavulanic acid $(20 / 10 \mu \mathrm{g})$, ceftaxidime $(30 \mu \mathrm{g})$, meropenem (10 $\mu \mathrm{g})$ and cefriazone $(30 \mu \mathrm{g})$ were used. The test was standardized using Mac Farland standard of $0.5[16,17]$.

\subsection{Statistical Analysis}

Statistical analysis was carried out using SPSS version 20.0 for the analysis of percentages [18].

\section{RESULTS AND DISCUSSION}

The poultry farming types and management attitudes of the poultry farms in Ido/Osi are represented in Table 1. Documented safety regulatory document was not available on all the examined farms. Few of the poultry farmers under survey, $16.7 \%$ adopted the free range system of farming while majority practiced the intensive system. Layers were the most reared. Accumulated poultry wastes were frequently disposed into open fields, pits and natural water bodies between 3 to 4 days. Among the three waste disposal options adopted on the farms, disposal into open field was the most adopted, $67 \%$. Besides, the collected poultry droppings were used as farm-yard manure by a significant breeders' population, $42 \%$. Family members were the major source of labor, $92 \%$ engaged as workers on the farm. There was contact between few poultry farmers, $8 \%$ and their clients during routine farming activities. Well was the main source of water used by majority, $83 \%$ of the farms. Hand glove was not used by majority $83.3 \%$ while coverall was used by few of the farmers, $8 \%$ as personal protective equipment.

The socio-demographic characteristics of the poultry farmers in the area of study are shown in Table 2. The data show that the business of poultry farming was mainly practiced by a population of married men with tertiary education $(83 \%)$. The age category of majority of the farming population, $75 \%$ was between $40-49$ years old.

The geographical coordinates of the area of study is represented in Table 3 . The area of study is located between latitudes 7.85408 to 7.8927 and longitudes 5.1833 to 5.1658 .

The proximity of poultry sites to natural water sources and human residence in the area of 
study is shown in Table 4. All the sampled poultry farms $(100 \%)$ were located in close proximity to residential sites. The distance of the poultry farms to human residential sites is between 4 meters to 6 meters while the proximity of poultry farms to natural water sources is between 160 meters to 4596 meters.

The natural water sources located within the area of study and their uses is shown in Table 5. The water bodies consist of spring and streams. They were used for religious, domestic, recreational, agricultural and construction purposes.

The antibiotics percentage resistant profile of. E. coli isolated is shown in Table 6 . Results of antibiotic sensitivity test show that multiple antibiotic-resistant bacteria were present in poultry droppings, waste water and soil from poultry-waste disposal sites. Bacterial resistance to the fluoroquinolones, sulphonamide, tetracycline, aminoglycoside and penicillin were considerably high.

The unsafe act audit of the poultry production sites links the safety of human health with the quality of water and soil in the environment. Unsafe acts and conditions with the inherent occupational hazards in poultry production sites are under-reported. The menace is attributed to non-functional health, safety and environment management system. Majority of the farmers adopted intensive system of farming but few still reared free range birds. Free range birds spread antibiotic resistant bacteria to human environment. Presence of poultry wastes in human environment constitutes an unsafe condition and further contributes to air, soil and water pollution. Also, contaminated open fields, pits and natural water sources used as disposal sites are reservoir of antibiotic-resistant bacteria present in poultry droppings. This observation is consistent with the findings of [1] that wastes generated on food animal production farms in Nigeria were dumped in heaps on farm lands or remote locations inside or close to water bodies. The use of collected poultry droppings as farm yard manure by a significant farming population increases human exposure to antibiotic resistant bacteria. Family members were the labor force on majority of the under-studied farms. Though engagement of family members as labor is considered cheap and readily available, they may be occupationally exposed to biological hazards such as multiple antibiotic resistant bacteria from poultry and consequently cripple family health. These findings agree with [19] that workers such as veterinarians, poultry farmers, abattoir workers and those directly in contact with animal products are occupationally exposed and at risk of contracting infection from multiple antibiotic resistant bacteria. Besides, the non-use of P. P. E during routine farming operations indicates that less attention was paid to bio-safety regulations. Non-usage of P. P. E constitutes an unsafe act that endangers the health of poultry workers. Agencies that promote H. S. E standards and policies prohibiting unsafe acts and conditions in poultry production sites should be mobilized in order to prevent spread of zoonosis of bacterial origin to man. The predominance of educated male population in the business of poultry underscores the importance of energy, commitment and education in effective poultry management operations. Besides, disease prevention and control in poultry management demands training and regular presence of poultry farmers on site. The status of marriage confers the responsibility of co-managing poultry farms on family members via delegation of duties. These findings are consistent with [18] who recorded $72 \%$ male and $71 \%$ poultry farming population with tertiary education.

The consumption of the natural water bodies sighted in the area of study for domestic religious, agricultural, recreational and construction purposes increases human exposure to multiple antibiotic-resistant bacteria present in the environment. Besides, about $12 \%$ of the respondents who were exposed to the natural water bodies had a previous history of diarrhea attributable to consumption of contaminated water in the environment. These finding agrees with [8] that antibiotic resistant bacteria may reach humans indirectly along the food chain through contact contaminated food and infected biological substances. Though backyard poultry farming is practiced for economic and food security purposes, it should be checked through licensing and E. I. A. operations. An inventory of potential hazards of poultry farming activities to the environment and public health should be carried out prior to and after localization of poultry sites to limit human exposure to risks associated with the occupation. The H. S. E. M. S should undertake public sensitization program on the inherent risks associated with biological hazards in poultry production sites in order to reduce it to ALARP.

Bacteria that are resistant to high profile antibiotics like fluoroquinolones, sulphonamide, 
tetracycline, aminoglycoside and penicillin are threat to public health. Safety in poultry production and environmental health should be improved by reviewing the national guidelines and standards for environmental pollution control. An inclusive strategy involving voluntary participation of poultry farmers and other stakeholders in health, safety and environment management system should be adopted to reduce the risks associated with poultry production to ALARP.

Table 1. Poultry farming types and management attitudes of the poultry farms in Ido/Osi, Ekiti State

\begin{tabular}{|c|c|c|}
\hline Characteristics & & Frequency (\%) \\
\hline \multirow[t]{2}{*}{ Ranging style of bird } & Intensive & $10(83.3)$ \\
\hline & Extensive & $2(16.7)$ \\
\hline \multirow[t]{5}{*}{ Types of bird } & Pullet/layer & $6(50)$ \\
\hline & Turkey & $2(16.7)$ \\
\hline & Broiler & $2(16.7)$ \\
\hline & Cockerel & $1(8.3)$ \\
\hline & Local breed & $1(8.3)$ \\
\hline \multirow[t]{3}{*}{ Age of birds (months) } & $>6$ months & $7(58.3$ \\
\hline & 2- 5 month & 4 (33.3) \\
\hline & 1 month & $1(8.3)$ \\
\hline \multirow[t]{2}{*}{ Scale of production } & Commercial & $10(83.3)$ \\
\hline & Subsistence & $2(16.7)$ \\
\hline \multirow[t]{3}{*}{ Predominant waste disposal options } & Open field & $8(66.7)$ \\
\hline & Buried & $3(25)$ \\
\hline & Into running water & $1(8.3)$ \\
\hline \multirow[t]{2}{*}{ Droppings used as farm yard manure } & No & $7(58.3)$ \\
\hline & Yes & $5(41.7)$ \\
\hline Period of disposing litters & 3-4 days & $12(100)$ \\
\hline \multirow[t]{2}{*}{ Attendance to client during activities } & No & $11(91.7)$ \\
\hline & Yes & $1(8.3)$ \\
\hline \multirow[t]{2}{*}{ Use of glove as personal protective equipment } & No & $10(83.3)$ \\
\hline & Yes & $2(16.7)$ \\
\hline Personal protective equipment used & Coverall & $1(100)$ \\
\hline \multirow[t]{2}{*}{ Major type of labour engaged on farm } & Family members & $11(91.7)$ \\
\hline & Others & $1(8.3)$ \\
\hline \multirow[t]{2}{*}{ Employment of services of consultant } & No & $10(83.3)$ \\
\hline & Yes & $2(16.7)$ \\
\hline \multirow[t]{2}{*}{ Water source } & Regular & $10(83.3)$ \\
\hline & Not regular & $2(16.7)$ \\
\hline \multirow[t]{2}{*}{ Major source of water on farm } & Well & $10(83.3)$ \\
\hline & Borehole & $2(16.7)$ \\
\hline \multirow[t]{2}{*}{ Major source of feed consumed } & Purchased & $9(75)$ \\
\hline & Self-composed & $3(25)$ \\
\hline \multirow[t]{2}{*}{ Name of purchased feed } & Brand a & $1(11.1)$ \\
\hline & Brand $\mathrm{b}$ & $8(88.9)$ \\
\hline Use of documented safety regulations & No & $12(100)$ \\
\hline
\end{tabular}


Table 2. Socio-demographic characteristics of the poultry farmers

\begin{tabular}{llll}
\hline Characteristics & & Frequency & Percentage (\%) \\
\hline Age of poultry farmers & $30-39$ & 1 & 8.3 \\
& $40-49$ & 9 & 75 \\
& $50-59$ & 1 & 8.3 \\
& 60 and above & 1 & 8.3 \\
\hline Gender & Male & 10 & 83.3 \\
& Female & 2 & 16.7 \\
\hline Level of education & Primary/ below & 1 & 8.3 \\
& Secondary & 1 & 8.3 \\
& Tertiary & 10 & 83.3 \\
\hline Marital status & Single (widow) & 1 & 8.3 \\
& Married & 11 & 91.7 \\
\hline
\end{tabular}

Table 3. Geographical system positioning coordinates of the area of study

\begin{tabular}{lll}
\hline Poultry sites & Latitude & Longitude \\
\hline A & 7.8927 & 5.1688 \\
B & 7.8668 & 5.1659 \\
C & 7.8667 & 5.1658 \\
D & 7.8667 & 5.1658 \\
E & 7.8740 & 5.1802 \\
F & 7.8566 & 5.1778 \\
G & 7.8547 & 5.1761 \\
H & 7.87234 & 5.1792 \\
I & 7.85408 & 5.1833 \\
J & 7.86719 & 5.1736 \\
K & 7.86588 & 5.1738 \\
L & 7.86148 & 5.1749 \\
\hline
\end{tabular}

Table 4. Proximity of poultry sites to natural water sources and human residence

\begin{tabular}{|c|c|c|c|c|c|c|}
\hline \multirow[t]{2}{*}{ Farm code } & \multirow{2}{*}{$\begin{array}{l}\text { human } \\
\text { residence }\end{array}$} & \multicolumn{5}{|c|}{ Distance of poultry sites to: natural water bodies } \\
\hline & & OGS & IGS & APL 1 & APL 2 & IJK \\
\hline A & 10 & 2458.8 & 2995.1 & 3231.9 & 1144.5 & 4595.9 \\
\hline B & 10.5 & 1566.8 & 596.1 & 1156.2 & 1867.6 & 1442.4 \\
\hline C & 10.5 & 1566.8 & 596.1 & 1156.2 & 1867.6 & 1442.4 \\
\hline D & 6.0 & 859.3 & 1090.9 & 2054.9 & 1628.2 & 2643.6 \\
\hline E & 5.0 & 1396.5 & 1717.8 & 800.35 & 1715.2 & 2836.9 \\
\hline $\mathrm{F}$ & 4.3 & 1516.8 & 974.6 & 1900.2 & 3007.2 & 625.5 \\
\hline $\mathrm{G}$ & 8.0 & 1663.1 & 1110.4 & 2161.3 & 3449.6 & 815.3 \\
\hline $\mathrm{H}$ & 8.0 & 999.2 & 990.9 & 379.4 & 1942.6 & 2155.8 \\
\hline I & 4.0 & 1807.1 & 1464.7 & 1814.2 & 3626.0 & 989.0 \\
\hline $\mathrm{J}$ & 4.5 & 389.7 & 565.7 & 1164.2 & 785.1 & 1442.4 \\
\hline K & 4.6 & 473.4 & 159.5 & 1141.6 & 2153 & 1530.5 \\
\hline L & 12 & 958.8 & 369.2 & 1529.6 & 2714.7 & 1233.2 \\
\hline
\end{tabular}


Table 5. Natural water sources located within the area of study and their uses

\begin{tabular}{|c|c|c|c|c|c|c|c|c|c|c|}
\hline No & Water bodies & Types & & & & Percentage 0 & use of the wate & bodies (\% & & Previous history of diarrhea attribu table to water use \\
\hline & & & Fishing & Domestic & Farming & Recreational & Construction & Religious & None & \\
\hline 1 & Ogudu & Stream & - & $1(10)$ & $3(30)$ & $2(20)$ & $2(20)$ & $2(20)$ & - & $2(20)$ \\
\hline 2 & Igemo & Spring & - & $1(10)$ & - & - & - & - & $9(90)$ & - \\
\hline 3 & Apalogbo I & Stream & $2(20)$ & $1(10)$ & $3(30)$ & - & $3(30)$ & - & $1(10)$ & $1(10)$ \\
\hline 4 & Apalogbo II & Stream & $1(10)$ & $3(30)$ & $1(10)$ & $5(50)$ & - & - & - & $3(30)$ \\
\hline 5 & ljokole & Stream & - & $3(30)$ & $5(50)$ & - & - & - & $2(20)$ & - \\
\hline & Total & & $3(6)$ & $9(18)$ & $12(24)$ & $7(14)$ & $5(10)$ & $2(4)$ & $12(24)$ & $6(12)$ \\
\hline
\end{tabular}

Table 6. Antibiotics percentage resistant profile of $E$. coli isolated

\begin{tabular}{|c|c|c|c|c|c|c|c|c|c|c|c|}
\hline \multirow[b]{2}{*}{ Source code } & \multirow[b]{2}{*}{$\mathbf{N}$} & \multicolumn{2}{|c|}{ Cephalosporin } & \multirow{2}{*}{$\begin{array}{l}\text { Penicillin } \\
\text { AMC (\%) }\end{array}$} & \multicolumn{2}{|c|}{ Fluoroquinolone } & \multirow{2}{*}{$\begin{array}{l}\text { Aminoglycoside } \\
\mathrm{CN}(\%)\end{array}$} & \multirow{2}{*}{$\begin{array}{l}\text { Caberpenem } \\
\text { MEM (\%) }\end{array}$} & \multirow{2}{*}{$\begin{array}{l}\text { Sulfonamide } \\
\text { SXT (\%) }\end{array}$} & \multicolumn{2}{|c|}{ Tetracycline } \\
\hline & & CRO (\%) & CAZ (\%) & & CIP (\%) & OFX (\%) & & & & TET (\%) & N (\%) \\
\hline A & 5 & 0 & 0 & $5(100)$ & $4(80)$ & $3(60)$ & $4(80)$ & 0 & $3(60)$ & $4(80)$ & $4(80)$ \\
\hline B & 3 & $1(33.3)$ & $1(33.3)$ & $3(100)$ & $1(33.3)$ & $1(33.3)$ & $1(33.3)$ & 0 & $1(33.3)$ & $3(100)$ & $3(100)$ \\
\hline C & 3 & 1 (33.3) & 1 (33.3) & $3(100)$ & 1 (33.3) & $2(66.7)$ & $3(100)$ & 0 & $2(66.7)$ & $2(66.7)$ & $3(100)$ \\
\hline D & 5 & $1(20)$ & $1(20)$ & $5(100)$ & $4(80)$ & $5(100)$ & $5(100)$ & 0 & $2(40)$ & $3(60)$ & $5(100)$ \\
\hline$E$ & 6 & 0 & 0 & $5(83.3)$ & $5(83.3)$ & $5(83.3)$ & $3(50)$ & $2(33.3)$ & $4(66.7)$ & 5 (83.3) & $6(100)$ \\
\hline $\mathrm{F}$ & 5 & $1(20)$ & $1(20)$ & $5(100)$ & $5(100)$ & $5(100)$ & $1(20)$ & $3(60)$ & $4(80)$ & $4(80)$ & $5(100)$ \\
\hline G & 8 & $5(62.5)$ & $5(62.5)$ & $2(25)$ & $8(100)$ & $6(75)$ & $3(37.5)$ & $3(37.5)$ & $6(75)$ & $7(87.5)$ & $8(100)$ \\
\hline $\mathrm{H}$ & 11 & 9 (81.9) & 8 (72.7) & $7(63.6)$ & $11(100)$ & $9(81.9)$ & 8 (72.7) & $1(8.7)$ & $11(100)$ & $11(100)$ & $11(100)$ \\
\hline 1 & 13 & $13(100)$ & $12(92.3)$ & 9 (69.2) & $11(84.6)$ & $12(92.3)$ & $13(100)$ & $9(69.2)$ & $10(76.9)$ & 10 (76.9) & $12(92)$ \\
\hline $\mathrm{J}$ & 12 & $11(91.7)$ & 10 (83.3) & 7 (58.3) & $12(100)$ & 10 (83.3) & 7 (58.3) & 7 (58.3) & 10 (83.3) & $11(91.7)$ & $12(100)$ \\
\hline $\mathrm{K}$ & 14 & $9(64.3)$ & $10(71.4)$ & $10(71.4)$ & $12(85.7)$ & $12(85.7)$ & $12(85.7)$ & $7(50)$ & $11(78.6)$ & $10(71.4)$ & $12(86)$ \\
\hline L & 5 & $5(100)$ & $4(80)$ & $4(80)$ & $5(100)$ & $5(100)$ & $4(80)$ & $4(80)$ & $5(100)$ & $1(20)$ & $5(100)$ \\
\hline F/W & - & - & - & - & & - & - & - & - & - & - \\
\hline DS & 4 & $4(100)$ & $3(75)$ & $3(75)$ & $3(75)$ & $3(75)$ & $4(100)$ & $2(50)$ & $4(100)$ & $2(50)$ & $4(100)$ \\
\hline Total & 94 & $60(63.8)$ & $56(60)$ & 68 (72.3) & $82(87.2)$ & $78(83)$ & 68 (72.3) & $38(40.4)$ & $73(77.7)$ & 73 (77.7) & $90(95.7)$ \\
\hline
\end{tabular}

Keys: $n=n u m b e r$ of isolates, $N$ - Number of isolates showing multiple antibiotic resistance, F/W-isolates from feed and water, DS-number of isolates from disposal site, OFX-Ofloxacin; CIP-Ciprofloxacin, GNGentamycin; AMC-Amoxycillin-clavulanate, CRO Cefriaxone; MEM-Meropenem, CAZ=Ceftaxidime TET=Tetracycline, SXT= Trimethoprim/Sulfamethoxazole. Source A-pullets, B-layers, C- broilers, D-broilers, E-,turkeys, F-,turkey, G-layers, H-layers, I- layers, J-cockerels, K-local birds, L-layer 


\section{CONCLUSION}

We have demonstrated that unsafe act audit of poultry production sites in this research links the safety of public health with the quality of water and soil in human environment. Unsafe acts and conditions with the inherent occupational and biological hazards in poultry production sites are attributed to non-functional health, safety and environment management system. Poultry droppings constitute biological hazard to public health. Human exposure to these biological hazards present in the environment predisposes the public to infections. Further studies that determine the die-off rates of these multiple antibiotic-resistant bacteria in abiotic conditions are required to determine the role of the environment as a source of spread.

\section{CONSENT}

As per international standard or university standard, respondents' written consent has been collected and preserved by the authors.

\section{ETHICAL APPROVAL}

It is not applicable.

\section{ACKNOWLEDGEMENTS}

The Poultry farmers who participated in the research and Technologists from Ekiti State University, Ado-Ekiti are appreciated for their painstaking directed to ensuring a comprehensive microbiological analysis.

\section{COMPETING INTERESTS}

Authors declare that no competing interests exist.

\section{REFERENCES}

1. Adelowo OO, Fagade OE, Agerso $\mathrm{Y}$. Antibiotic resistance and resistance genes in Escherichia coli from poultry farms, southwest Nigeria. Journal of Infection in Developing Countries. 2014;8(9):11031112.

2. Roy K, Lebens $M$, Svennerholm A, Teneberg S. Enterotoxigenic Escherichia coli Etpa mediates adhesion between flagella and host cells. Nature. 2009; 457:594-598.
3. Nhung TN, Niwat CN, Carrique-Mas JJ. Antimicrobial resistance in bacterial poultry pathogens: A review. Front Veterinary Science. 2017;4:126.

4. Yassin AK, Gong J, Kelly P, Lu G, Guardabassi L, Wei L. Antimicrobial resistance in clinical Escherichia coli isolates from poultry and livestock, China. PLoS ONE. 2017;12(9):0185326.

5. Martinez JL. Environmental pollution by antibiotics and by antibiotic resistance determinants. Environmental Pollution. 2009;157:2893-2902.

6. Marathe NP, Regina VR, Walujkar SA, Charan SS, Moore ERB, Larsson DGJ. A treatment plant receiving waste water from multiple bulk drug manufacturers is a reservoir for highly multi-drug resistant integron-bearing bacteria. PLoS ONE. 2013;8(10):e77310.

7. Graham DW, Collignon P, Davies J, Larsson DGJ, Snape J. Underappreciated role of regionally poor water quality on globally increasing antibiotic resistance. Environmental Science and Technology. 2014;48(20): 11746-11747.

8. Chang Q, Wang W, Regev-Yochay G, Lipsitch M, Hanage WP. Antibiotics in agriculture and the risk to human health: How worried should we be?. Evolutionary Application. 2015;8:240-245.

9. Davis GS, Waits K, Nordstrom L, Weaver B, Aziz M, Gauld L, et al. Intermingled Klebsiella pneumoniae populations between retail meats and human urinary tract infections. Clinical Infectious Diseases. 2015;61(6):892-899.

10. Börjesson $S$, Ny S, Egervärn M, Bergström $J$, Rosengren A, Englund S, et al. Limited dissemination of extended-spectrum $\beta$ lactamase and plasmid encoded AmpCproducing Escherichia coli from food and farm animals, Sweden. Emerging Infectious Diseases. 2016;22(4):15.

11. Garcia-Graells C, Antoine JL, Catry B, Skov R, Dennis O. Livestock veterinarians at risk of acquiring methicillin-resistant Staphylococcus aureus ST39. Epidemiology and Infection. 2012;140(3): 383-389.

12. Köck R, Loth B, Köksal M, Schulte-Wülwer J, Harlizius J, Friedrich AW. Persistence of nasal colonization with livestockassociated methicillin-resistant Staphylococcus aureus in pig farmers after holidays from pig exposure. Applied 
Environmental Microbiology. 2012;78(11): 4046-4047.

13. Price LB, Stegger M, Hasman H, Aziz M, Larsen J, Andersen PS, et al. Staphylococcus aureus CC398: Host adaptation and emergence of methicillin resistance in livestock. MBio. 2012;3(1): 305-311.

14. Wampler PJ, Rediske RR, Molla AR. Using arc map, google earth, and global positioning systems to select and locate random households in rural Haiti. International Journal of Health Geographics. 2013;12(3):12-13.

15. leven ME, Vercauteren $P$, Descheemaeker F, Van Laer F, Goossens H. Comparison of direct plating and broth enrichment culture for the detection of intestinal colonization by glycopeptide-resistant Enterococci among hospitalized patients. Journal of Clinical Microbiology. 1999;37 (5):1436-1440.
16. Muhammad AA, Hassan SMR, Saidul A, Momena, S. Antibiotic resistance of Escherichia coli isolated from poultry and poultry environment of Bangladesh. American Journal of Environmental Sciences. 2009;5(1):47-52.

17. CLSI. Performance standards for antimicrobial disk susceptibility tests. Approved standard-eleventh edn. CLSI document M02-A11. Wayne, PA, USA; 2013.

18. Adebowale OO, Adeyemo OK, Awoyomi $\mathrm{O}$, Dada R. Antibiotic use and practices in commercial poultry laying hens in Ogun State Nigeria. Revue d. Elevage et de. Medecine Veterinaire des Pays Tropicaux. 2016;67(1):41-45.

19. Marshall, BM, Levy SB. Food animals and antimicrobials: Impacts on human health. Clinical Microbiology Reviews. 2011;24: 718-733.

(c) 2021 Oluyege and Ojo; This is an Open Access article distributed under the terms of the Creative Commons Attribution License (http://creativecommons.org/licenses/by/4.0), which permits unrestricted use, distribution, and reproduction in any medium, provided the original work is properly cited.

Peer-review history:

The peer review history for this paper can be accessed here: https://www.sdiarticle5.com/review-history/65521 